\title{
LEGIBILITY
}

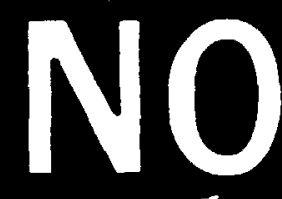

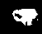

A major purpose of the Technical Information Center is to provide the broadest dissemination possible of information contained in DOE's Research and Development Reports to business, industry, the academic community; and federal, state and local governments.

Although a small portion of this report is not reproducible, it is being made available to expedite the availability of information on the research discussed herein. 


\title{
HEALTH AND SAFETY RESEARCH DIVISION
}

Waste Management Research and Development Programs

(Activity No. AH 100500 0; NEAH001)

\section{RESULTS OF THE RADIOLOGICAL SURVEY AT DIEBOLD SAFE COMPANY, 1550 GRAND BOULEVARD, HAMILTON, OHIC (HOOO1)}

\author{
R. D. Foley and L. M. Floyd \\ Date Published - February 1990 \\ Investigation Team \\ R. E. Swaja - Measurement Applications and Development Manager \\ W. D. Cottrell - FUSRAP Project Director \\ R. D. Foley - Field Survey Supervisor \\ Survey Team Members \\ L. C. Johnson* \\ J. L. Quillen \\ R. A. Mathis \\ P. F. Tiner \\ * Don Stone Associates \\ †Former Employee of Martin Marietta Energy Systems, Inc. \\ Work performed by the \\ MEASUREMENT APPLICATIONS AND DEVELOPMENT GROUP \\ Prepared by the

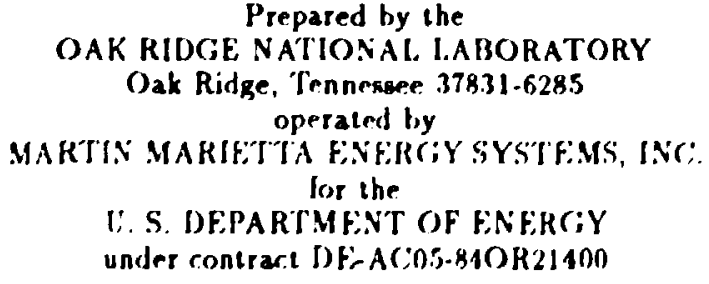




\section{CONTENTS}

LIST OF FIGURES . . . . . . . . . . . . . . . . . v

LIST OF TABLES $\ldots \ldots \ldots \ldots \ldots$ vii ACKNOWLEDGMENTS . . . . . . . . . . . . ix ABSTRACT .........................

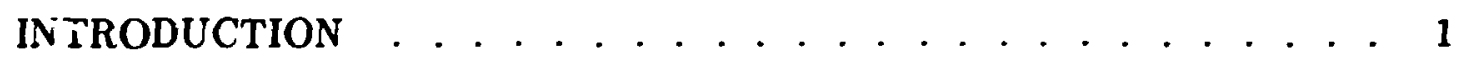

SURVEY METHODS ................... 2

SURVEY RESULTS . . . . . . . . . . . . . . . 3

Outdoor Survey Results . . . . . . . . . . . . . . 3

Gamma Radiation Levels . . . . . . . . . . . . . . . . . . . 3

Systematic Soil Samples. . . . . . . . . . . . . . . . 3

Alpha and Beta-Gamma Measurements . . . . . . . . . . 4

Indoor Survey Results . . . . . . . . . . . . . . . . . . . 4

Gamma Radiation Levels . . . . . . . . . . . . . . . . . . . . 4

Systematic and Biased Samples . . . . . . . . . . . . . . . . . 5

Alpha and Betz Gamma Measurements . . . . . . . . . . . . . 6

Air Samples . . . . . . . . . . . . . . . . 6

SIGNIFICANCE OF FINDINGS . . . . . . . . . . . . . . . . . . . 6

REFERENCES . . . . . . . . . . . . . . 7 


\section{LIST OF FIGURES}

1 View of the main entrance to the building at Diebold Safe Company, 1550 Grand Boulevard, Hamilton, Ohio (HO001), from Mosler Avenue

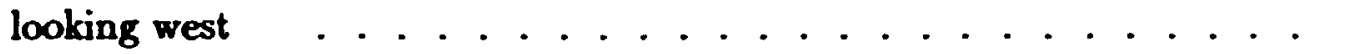

2 View of the back of the building at Diebold Safe Company, 1550 Grand Boulevard, Hamilton, Ohio (HO001), from Erie Highway looking north . 9

3 Interior view of the building at Diebold Safe Company, 1550 Grand Boulevard, Hamilton, Ohio (HO001), showing one high bay area with

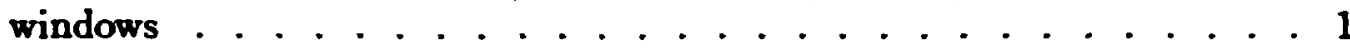

4 Interior view of the building at Diebold Safe Company, 1550 Grand Boulevard, Hamilton, Ohio (HO001), showing the cross braces . . . 11

5 Gamma radiation levels $(\mu \mathrm{R} / \mathrm{h})$ measured both indoors and outdoors at Diebold Safe Company, 1550 Grand Boulevard, Hamilton, Ohio (HO001) . . . . . . . . . . . . . . . 112

6 Diagram showing locations of soil, dust, debris, and air samples taken at Diebold Safe Company, 1550 Grand Boulevard, Hamilton, Ohio (HO001) . . . . . . . . . . . . . . . 1 


\section{LIST OF TABLES}

1 Applicable guidelines for protection against radiation $\ldots \ldots 14$

2 Background radiation levels for the Ohio area outdoors . . . . . . 15

3 Concentrations of radioruclides in outdoor soil samples from Diebold Safe Company, 1550 Grand Boulevard, Hamilton, Ohio (HO001) . . 16

4 Concentrations of radionuclides in indoor dust, debris, and polishing compound samples from Diebold Sare Company, 1550 Grand Boulevard, Hamilton, Ohio (HO001) . . . . . . . . . . 17

5 Concentrations of radionuclides in air samples from Diebold Safe Company, 1550 Grand Boulevard, Hamilton, Ohio (HO001) . . . . . . . . 18 


\section{ACKNOWLEDGMENTS}

Research for this project was sponsored by the Division of Facility and Site Decommissioning Projects, U.S. Department of Energy, under contract DE-ACOS84OR21400 with Martin Marietta Energy Systems, Inc. The authors wish to acknowledge the support of J. E Baublitz, Acting Director, Office of Remedial Action and Waste Technology: J. J. Fiore, Director, Division of Facility and Site Decommissioning Projects; and members of their staffs. The authors ako appreciate the contributions of J. L Rich, S. W. Hawthome, B. C. Litteton, and L J. Jeffers of the Publications Division; D. A Roberts and T. R. Stewart of the Measurement Applications and Development Group; J. L Quillen, former employee of Martin Marietta Energy Systems, Inc; and L. C. Johnson of Don Stone Associates for participation in the collection, analyses, editing, and reporting of data for this survey. 


\begin{abstract}
At the request of the U.S. Department of Energy (DOE), a group from Oak Ridge National Laboratory conducted investigative radiological surveys at Diebold Safe Company, 1550 Grand Boulevard, Hamilton, Ohio (HO001) in 1988 and 1989. The purpose of the surveys was to determine whether the property was contaminated with radioactive residues, principally ${ }^{20} \mathrm{U}$, derired from the former Manhattan Engineer District (MED) project. The surveys included gamma scans; direct and transferable measurements of alpha, veta, and gamma radiation levels; and dust, debri, air, and soil sampling for radionuclide analyses.

Results of the survy a monstrated no radionuclide concentrations in excess of the DOE Formerty Utilized Sites Remedial Action Program criteria for ais and soil samples remaining at the site. All but three dust and debris samples were below federal guidelines and contained very low levels of radium, thorium, and uranium. Small fragments of uranium metal left from the machining operation were believed to be the source of elevated radionuclides in the three samples above DOE criteria. After removal of these samples, no beta or gamma radiation above background could be detected.
\end{abstract}




\section{RESULTS OF THE RADIOLOGICAL SURVEYS AT DIEBOLD SAFE COMPANY, 1550 GRAND BOULEVARD, HAMILTON, OHIO (HOOO1)*}

\section{INTRODUCTION}

Under jurisdiction of the Army Corps of Engineers in the early 1940s, the Manhattan Engineer District (MED) was established as the lead agency in the development of nuclear energy for defense-related projects. Raw materials containing uranium ores were procured, stored, and processed into various uranium oxides, salts, and metals. Fabricators were contracted as needed to form (roll and machine) the metal into various shapes. At contract termination, sites used by contractors were decontaminated according to the criteria and health guidelines then in use. The radiological criteria for releasing sites to unrestricted ust were generally site specific and clearly defined. In some instances, however, documentation was limited or nnnexistent and conditions at these sites were unknown. Therefore, it was necessary to reevaluate the current radiological conditions at these sites under the U.S. Department of Energy (DOE) Formerly Utilized Sites Remedial Action Program (FUSRAP).

Intermittently from the 1940 s to the early 1950s, the Herring-Hall-Marvin Safe Company (HHMSC) in Hamilton, Ohio machined uranium slugs from rolled stock under subcontract to the MED. This commercial property was later purchased by the Diebold Safe Company and is located at 1550 Grand Boulevard, Hamilton, Ohio.

The facility is a large, roughly rectangular building $\left(\sim 300,000 \mathrm{ft}^{2}\right)$, constructed mostly of wood (Figs. 1 and 2). The interior is an open design with few walls and a support structure of columns and beans with cross braces (Figs. 3 and 4). High bays are offset by rows of windows at the ceiling (Fig. 3). The uranium metal was delivered via the former railroad tracks through the western sidc of the building and brought into the machining area (Fig. 5). The approximate area in which the uranium had been machined was established through conversations with Corporate officials and from marked drawings furnished by them (Fig. 5). The operation was carried out in the midst of a large machine room. In a correspondence dated August 4, 1943, three machines used in this process were identified by number: Two of these machines were located on old floor plans of the HHMSC. One Cleveland Automatic Machine, No. 115, was just north of column P/10. One J.\&zL. Turret Lathe, No. 282, was located north of and between columns P/16-17. Two Acme Turret Lathes were located north of and betwecn columns $P / 20-21$ and $S / 20-21$, respectively. These lathes werc used in machining the $1 \frac{3}{8}$-inch billets of uranium. The metal was fionded with a water-soluble cooling oil while being machined. However, company correspondence indicated that occasionally limited quantities of the pyrophoric uranium spontancously ignited.

\footnotetext{
*The survey was performed by members of the Measurement Applications and Development Group of the Ilealth and Safety Research Division at Oak Ridge National Laboratory under DOF: contract DFr-AC:05-840R21400.
} 
The uranium machining activity was relatively small scale and appears to hive covered short periods of time. Therefore, levels of residual uranium and any resulting expositre were expected to be insignificant. Radiological surveys of the facility were necessary to verify whether the site meets current radiological guidelines. As a result of the Energy and Water Appropriations Act of Fiscal Year 1984, this froperty was included as a possible decontamination research and development project under FUSRAP. The principal radionuclide of concern is ${ }^{238} \mathrm{U}$.

On August 29 and 30, 1988, a radiological survey at 1550 Grand Boulevard was conducted, at the request of DOE, by members of the Measurement Applications and Development Group of the Oak Ridge National Laboratory (ORNL). The surveys and sampling covered portions of the exteric: ground surface, roof section above the uranium machining area, and the interior of the huilding. Survey emphasis was on the interior floor, the mezzanine, overhead beams of the uranium work station and the adjacent area, as well as the air in the uranium work station area. The rest of the building was also surveyed but with less intensity. On April 24, 1989, an ORNL survey team returned to the Diebold site for additional indoor sarnpling.

\section{SURVEY METHODS}

The radiological surveys included: (1) a gamma scan of the surface of the entire property outdoors and indoors, as well as the section of the roof over the machining area; (2) collection and radionuclide analyses of indoor debris scraped from the floor near the machining area, composite dust samples from selected beams in and around this area, a sample of Bison Satin Finish Buffing and Polishing Compound, one sanding belt, and outdoor surface soil samples; (3) direct and transferable alpha and beta-gamma activity levels in this and adjacent areas and on the roof above; and (4) air sampling of the same areas.

To provide better definition of the area to be surveyed, the site was subdivided into grid blocks based on the cxisting columns, as shown in Fig. 5. The columns were numbered, west to east, and lettered, south to north. The columns represent the intersection of grid lines. These intersections are referenced in the text with a slash, as $\mathrm{T} / 18$. Using a portable Victoreen gamma scintillation meter, a gamma scan was performed indoors in each accessible grid block, outdoors adjacent to the building, and on the roof above the machining area between columns $P$ and $T$. The detectors were held approximately three inches above the ground surface or floor, and ranges of measurements were recorded. If the garr.ma levels wer:: elevated, a biased sample was taken at the point showing the highest ga.ll:1a radiation level. These samples are more likely to contain elevated radioactivity than systematic samples. Systematic samples were taken at various locations, both indoxors and outdoors, irrespective of gamma radiation levels. Systernatic, composite dust samples were collected from the tops of preselected beams and combined (Fig. 6). The composite dist samples were also taken independently of gamma activity; they were collected to obtain a general representation of the: radionuclide levels above and surrounding the machining area. The samples were analyzed for ${ }^{232}$ Th and ${ }^{238} \mathrm{U}$ content, $\therefore \cdot d$ in some cases, ${ }^{226} \mathrm{Ra}$. 
High bays between columns $K$ and $P$, as well as $T$ and $W$, generally prevented scanning or collecting dust samples from the beams in these areas, except for the beams accessible from the mezzanine (Fig. 3). The beams above the mezzanine at column $\mathrm{P}$ were surveyed to some extent from the roof through the windows.

On surfaces in areas of possible contamination and/or where exposure rates were elevated, beta-gamma dose rate measurements were determined using a GM pancake type probe with either a Technical Associates Instrument or a Rascal; and alpha activity levels were determined using a beer-mug type probe with an alpha scintillation meter. Smears from $100 \mathrm{~cm}^{2}$ areas were also obtained from selected surfaces of the beams in the composite areas and on the roof. The purpose of the smears was to establish transferable alpha and beta-gamma activity levels.

In the April survey of the site, three indoor air samples were taken approximately $1.5 \mathrm{~m}$ above floor level using two Gast vacuum pumps with milipore paper filters $(0.8 \mu \mathrm{m})$ at a rate of $22.6 \mathrm{~L} / \mathrm{min}$. Air samples were taken near areas of elevated gamma activity or radionuclide concertrations. Additional systematic and biased samples were taken indoors also. These survey methods followed the plan outlined in Reference 2. A comprehensive description of the survey methods and instrumentation has been presented in another report. ${ }^{3}$

\section{SURVEY RESULTS}

Applicable DOE residual radioactivity guidelines for protection of the general public are summarized in Table $1 .{ }^{4 a n d} \xi$ The normal background radiation levels for the Ohio area are presented in Table $2 .^{\circ}$ These data are provided for comparison with survey results presented in this section. All direct measurement results presented in this report are gross readings; background radiation levels have not been subtracted. Similarly, background concentrations have not been subtracted from radionuclide concentrations measured in environmental samples. Transferable radioactivity levels (smears) are reported as net counts with background subtracted.

\section{Outdoor Survey Results \\ Gamma Radiation Levels}

Gamma radiation levels measured during a scan of the surface of the property outdoors are given in Fig. 5. Gamma exposure rates ranged from 7 to $8 \mu R / h$. Measurements on the roof between columns $P$ and $T$ and also from the window ledges above the mezzanine ranged from 2 to $4 \mu \mathrm{R} / \mathrm{h}$; however, a new roof had been installed within the last five years. None of the levels were elevated.

\section{Systematic Soil Samples}

Systematic soil samples were taken from three locations on the property outdoors for radionuclide analyses. Locations of the systematic (S) samples are shown in Fig. 6, with results of laboratory analyses provided in Table 3. Since elcvated gamma levels were not detected outdorss, hiased samples were not taken. 
Concentrations of radium, thorium, and uranium in these samples ranged from 0.97 to $1.22 \mathrm{pCi} / \mathrm{g}, 0.59$ to $0.78 \mathrm{pCi} / \mathrm{g}$, and 1.38 to $1.55 \mathrm{pCi} / \mathrm{g}$, respectively. $\mathrm{DOE}$ guidelines for uranium are derived on a site-specific basis. While none have been derived for this site, guidelines for ${ }^{238} \mathrm{U}$ typically range between 35 and $150 \mathrm{pCi} / \mathrm{g}$. Radionuclide concentrations in all samples were below DOE criteria (Table 1) and were not significantly different from normal background levels for the Ohio area (Table 2).

\section{Alpha and Beta-Gamma Measurements}

Measurements of direct and transferable radioactivity levels were taken on the roof above columns $I$ through $T$ and from the window ledges above she mezzanine. All direct alpha measurements (six) in these areas were at or vear the minimum detectable amount (MDA) of $<30$ disintegrations per minute $(\mathrm{dpm})$ per $100 \mathrm{~cm}^{2}$ and well below DOE guidelines for fixed uranium concentration (Table 1). Direct beta-gamma surface activity levels for the six measurements in these areas were also below the MDA of $0.05 \mathrm{mrad} / \mathrm{h}$ and were well below government criteria for beta-gamma dose rates (Table 1).

Three smear samples were obtained from the same areas as the direct measurements. Analyses of the smears showed all measurements of transferable alpha and beta-gamma radiation from a $100 \mathrm{~cm}^{2}$ area were below the MDA's of $10 \mathrm{dpm}$ and $120 \mathrm{dpm}$, respectiveiy, as well as below DOE guidelines for removable uranium (Table 1).

\section{Indoor Survey Results \\ Gamma Radiation Levels}

Gamma radiation levels measured during a scan of the floor inside the building are given in Fig. 5. Gamma exposure rates generally ranged from 2 to $13 \mu \mathrm{R} / \mathrm{h}$. The highest gamma levels were 20 to $22 \mu \mathrm{R} / \mathrm{h}$ from a skid of rock salt, located at column V/9; such measurements are common in compounds containing potassiur.. The brick walls measured from 7 to $16 \mu \mathrm{R} / \mathrm{h}$, and the concrete floor gencrally ranged from 2 to $3 \mu \mathrm{R} / \mathrm{h}$. This slight elevation in gamma levels emanating from the brick is typical of the naturally occurring radioactive substances present in bricks, granite, and other such materials used in building construction.

A second area of slight elevation was detected near a skid containing a polishing compound. The Bison polishing compound measured $15 \mu \mathrm{R} / \mathrm{h}$; a biased sample of it was taken for analyses. An opened box of sanding belts found in a supply storage area between columns $S / 14-17$ and $T / 14-18$ measured $11 \mu R / h$. Several other factory sealed boxes of these belts gave approximately the same levels. Onc new belt was taken for gamma spectrographic analysis. The rock salt, polishing compound, and sanding belts were items used by the building owner in current operations.

Another slightly elevated level of $13 \mu \mathrm{R} / \mathrm{h}$ was in an arca formerly equipped with an Acme turret lathe near column $\mathrm{S} / 21$; a scraping of the floxr was taken from this location. This elevated arca consisted of two small spots, totaling approximately $0.4 \mathrm{~m}^{2}$ in surface area, and appeared to be underlain by debris and loose 
concrete. The contamination was ascertained to be on top of the tar-like debris and loose concrete. The last spot of slight elevation was found between columns $T / 18$ and $T / 19$, a second floor scraping was taken here. Only these last two areas on the floor were indicative of residual radioactivity associated with the former MED/AEC activities in the building. None of the direct measurements were above DOE guidelines for indoor gamma radiation levels (Table 1).

\section{Systematic and Biased Samples}

In August and again in April, dust and debris samples collected from various surfaces inside the building were analyzed for specific radionuclides; these results are provided in Table 4. Their locations are shown in Fig. 6 (S and B).

In the August survey, two systematic dust samples were taken from the tops of two beams off the mezzanine (sample S2 from i diagonal brace at column P/20 and sample S3 from the beam north of $P / 10$ ). In addition, three composite dust samples (S1, S4, and S5) were systematically taken from the locations shown in Fig. 6 as variously shaded areas. The composite dust samples were made up of dust collected from several locations and combined. Each shading type represerts the beams from which dust was collected for one composite sample Concentrations of radium, thorium, and uranium in the systematic and composite samples ranged from 0.40 to $1.19 \mathrm{pCi} / \mathrm{g}, 0.22$ to $0.89 \mathrm{pCi} / \mathrm{g}$, and 1.72 to $14.67 \mathrm{pCi} / \mathrm{g}$, respectively. The highest value of $14.67 \mathrm{pCi} / \mathrm{g}$ for systematic samples was from sample S3 near column P/10, the former location of the Cleveland Automatic Machine. In April, two more systematic dust samples (S9 and S10) were taken in the same manner as samples S2 and S3, near the S3 sample location. Sample S9 was taken from an area approximately $1 \mathrm{~m}$ atove and $1 \mathrm{~m}$ south of the sample S3. Sample S10 was taken approximately $1 \mathrm{~m}$ east and $2 \mathrm{~m}$ above the S3 location. Radionuclide concentrations in both of these later samples were less than the concentrations in S3. With the exception of sample S3, all systematic sample values were below applicable government guidelines (Table 1)

As mentioned previously, the first two biased debris samples were scraped from the floor during the August survey; sample B1 was near column S/21 and sample B2 was between columns $\mathrm{T} / 18$ and $\mathrm{T} / 19$. These debris samples were a combination of oil, dirt, dust, and sanding residue which had been compacted on the concrete floor over the years into a tarry, asphalt-like material. The debris samples were analyzed for thorium end uranium content, with concentrations ranging from 0.09 to $0.48 \mathrm{pCi} / \mathrm{g}$ for thorium-232 and from 26 to $2000 \mathrm{pCi} / \mathrm{g}$ for uranium-238. The maximum uranium concentration for the $\mathrm{B} 1$ debris sample was greater than the concentration limit derived by DOE for nonhomogeneous contamination at several other sites; these guidelir.es are summarized in Table 1. However, the contaminated area proved to be isolated and small in surface area (approximately $0.4 \mathrm{~m}^{2}$ ). As discussed in the next paragraph, further sampling removed any remaining contaminated debris.

During the April survey, the B1 sample location was resurveyed. Two small areas within this location were identified containing gumma activity slightly above background levels. The areas measured approximately $18 \times 24$ in. and $10 \times 18$ in. This part of the floor had been patched some time in the past. The contamination 
was on the original concrete and on the patch. The concrete and the patcli material were chipped out and removed from these two elevated sections. Dust and fines resulting from the chipping operation were swept from the bot tom of the holes and analyzed for uranium as sample B4. This material had a ${ }^{238} \mathrm{U}$ concentration of $38 \mathrm{pCi} / \mathrm{g}$, down from the original concentration of $2000 \mathrm{pCi} / \mathrm{g}$ in sample $\mathrm{Bl}$ during the first survey of the same area. Concrete and patch material we.e removed until the direct beta-gamma surface measurements in the chipping zone were indistinguishable from the background levels of unaffected concrete in other parts of the building. Though not specifically derived for this site, guidelines for ${ }^{238} \mathrm{U}$ at other sites typically range between 35 and $150 \mathrm{pCi} / \mathrm{g}$. Radionuclide concentrations in sample B4 were below DOE criteria for isolated areas of less than $1 \mathrm{~m}^{2}$ (Table 1 ).

Biased sample B3 was from the Bison polishing compound. The polishing compound sample was found to have $2.05 \mathrm{pCi} / \mathrm{g}$ of thorium-232 and $0.68 \mathrm{pCi} / \mathrm{g}$ of uranium-238. One of the sanding belts was analyzed for radium, thorium, and uranium content. Assuming $100 \%$ of the belt mass contained radioactive materials, the radionuclide concentrations were $1.85,2.54$, and $3.1 ! \mathrm{pCi} / \mathrm{g}$, respectively. Assuming only $40 \%$ ni the belt mass contained radioactive materials, the values were $5.13,7.03$, and $8.57 \mathrm{pCi} / \mathrm{g}$, respectively.

\section{Alpha and Beta-Gamma Measurements}

Measurements of direct and transferable radioactivity levels were taken from selected beam surfaces in the composite s.umple areas. All 37 direct alpha measurements on these beams were below the MDA of $<30 \mathrm{dpm} / 100 \mathrm{~cm}^{2}$ and well below DOE guidelines for fixed uranium (Table 1). Direct beta-gamma surface activity levels for the 37 measurements on these beams were also below the MDA of $0.05 \mathrm{mrad} / \mathrm{h}$ and well below government criteria for beta-gamma dose rates (Table 1).

Thirty seven smear samples were obtained from the same areas as the direct measurements. Analyses of the smears showed all measurements of transferable alpha and beta-gamma radiation from a $100 \mathrm{~cm}^{2}$ area were below the MDA's of $10 \mathrm{dpm}$ and $120 \mathrm{dpm}$, respectively, as well as below DOE guidelines for removable uranium (Table 1).

\section{Air Samples}

During the April survey, three indoor air samples were collected; results are given in Table 5. The locations of the air samples (Z) are shown in Fig. 6. Samples $\mathrm{Z1}$ and $\mathrm{Z3}$ were taken at column S/21, approximately five feet from sample location B1. Sample Z2 was taken at column S/11, near sample location S3. The samples were analyzed for gross alpha and beta radiation. The alpha activity for a oneminutc count was below the MDA level of $1.03 \mathrm{E}-12 \mu \mathrm{Ci} / \mathrm{cc}$ for alpha. The beta activity for a one--minute count was not statistically different from the MDA level of $1.77 \mathrm{E}-11 \mu \mathrm{Ci} / \mathrm{cc}$ for beta. 


\section{SIGNIFICANCE OF FINDINGS}

Radiological assessments of dust and debris samples from 1550 Grand Boulevard demonstrated very low levels of radium, thorium, and uranium, with the exception of dust sample $\mathbf{3 3}$ and the two biased floor samples B1 and B2. Values for ${ }^{238} \mathrm{U}$ in these three samples (S3, B1, and B2) measured $14.67 \mathrm{pCi} / \mathrm{g}$ for S3, $2000 \mathrm{pCi} / \mathrm{g}$ for $\mathrm{B} 1$, and $26 \mathrm{pCi} / \mathrm{g}$ for B2. Since there were no significantly elevated gamma ievels in these areas, the source of this elevated radionuclide is believed to be small fragments of the uranium metal itself left from the machining operation and removed with the samples. After removal of the thin layers of debris and concrete at the B1 and B2 locations, no beta or gamma radiation above background could be detected. Based on the S9 and S10 samples taken around S3, the elevated concentration of uranium in dust sample S3 appears to have been confined to a small area and not widespread. Air samplee (Z1-3) in these areas were below MDA for alpha and beta levels. All dust sample levels were between 3 and $10 \%$ of guidelines for removable surface contamination for ${ }^{238} \mathrm{U}$. Assuming all activity in the highest composite dust sample (S5) had been collected from one beam, the level would only be $40 \%$ of the DOE guidelines (Table 1). Radionuclide concentrations in soil samples from the site were not significantly different from normal background levels for the Ohio area (Table 2).

\section{REFERENCES}

1. W. D. Morwood, M.D., Metallurgical Laboratory, Hamilton, Ohio, to H. L. Henkel, Herring-Hall-Marvin Safe Company, 1550 Grand Boulevard, Hamilton, Ohio, correspondence (August 4, 1943).

2. W. D. Cottrell, ORNL, to A. J. Whitman, DOE/HQ, correspondence, "Radiological Survey of Private Properties in Lodi, New Jersey" (August 15, 1984).

3. T. E. Myrick, B. A. Berven, W. D. Cottrell, W. A. Goldsmith, and F. F. Haywood, Procedures Manual for the ORNL Radiological Survey Activities (RASA) Program Oak Ridge National Laboratory, ORNL/TM-8600 (A Aril 1987).

4. U.S. Department of Energy, Guidelines for Residual Radioactive Material at Formerly Utilized Sites Remedial Action Program and Remote Surplus Facilities Management Program Sites (Rev. 2, March 1987).

5. Nuclear Regulatory Commission, NRC Guidelines for Decontannination at Facilities and Equipment Prior to Release for Unrestricted Use or Termination of Licenses for PV-Product, Source, or Special Nuclear Material (May 1987).

6. T. E. Myrick, B. A. Berven, and F. F. Haywood, State Background Radiation Levels: Results of Measurements Taken During 19751979, Oak Ridge National Laboratory, ORNL/TM-7343 (November 1981). 
ORNL-PHOTO 89-1420

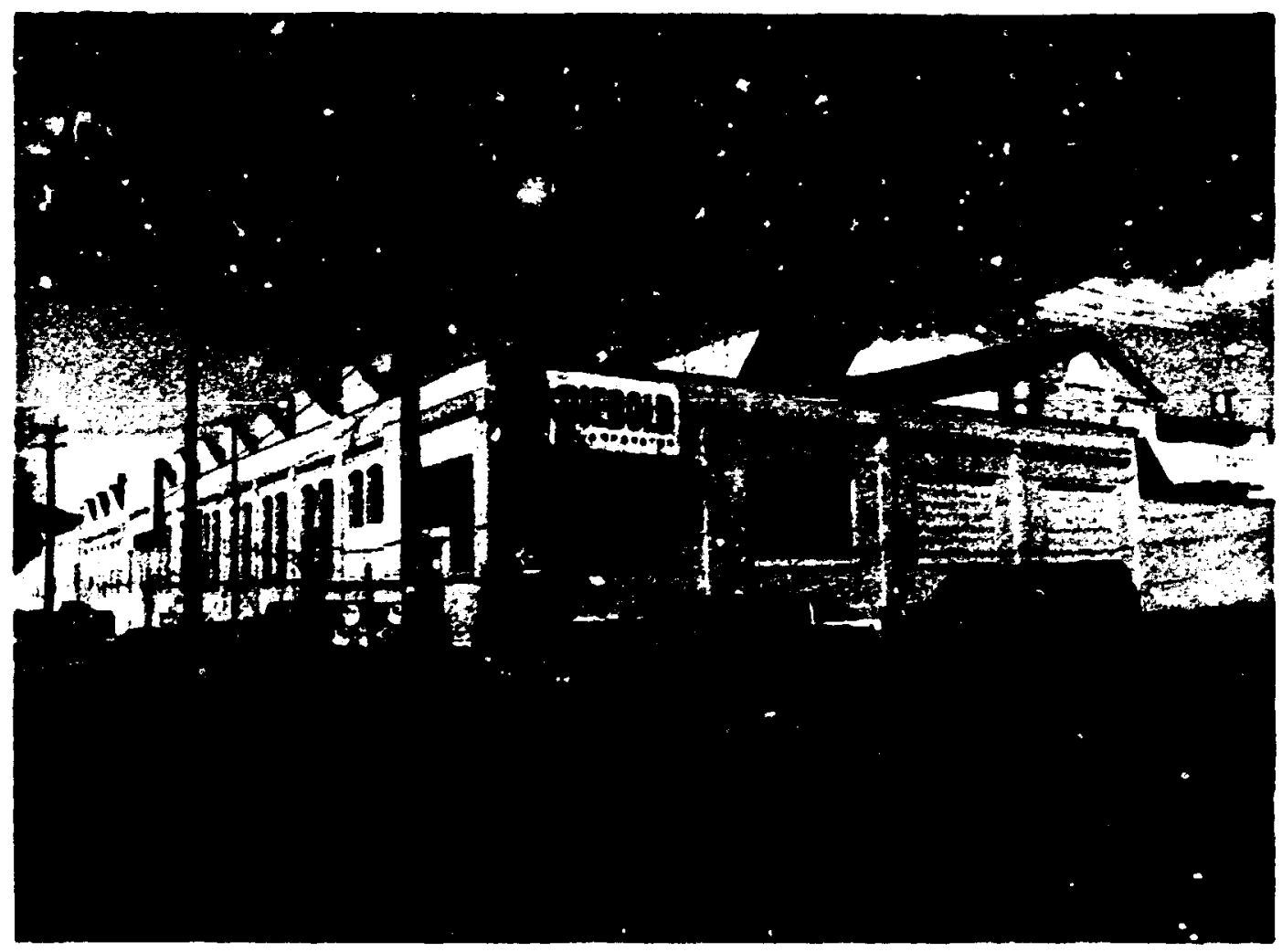

Fig. 1. View of the main entrance to the building at Diebold Safe Company, 1550 Grand Boulevard, Hamilton, Ohio (HO001), from Mosler Avenue looking west. 
ORNL-PHOTO 89-1421

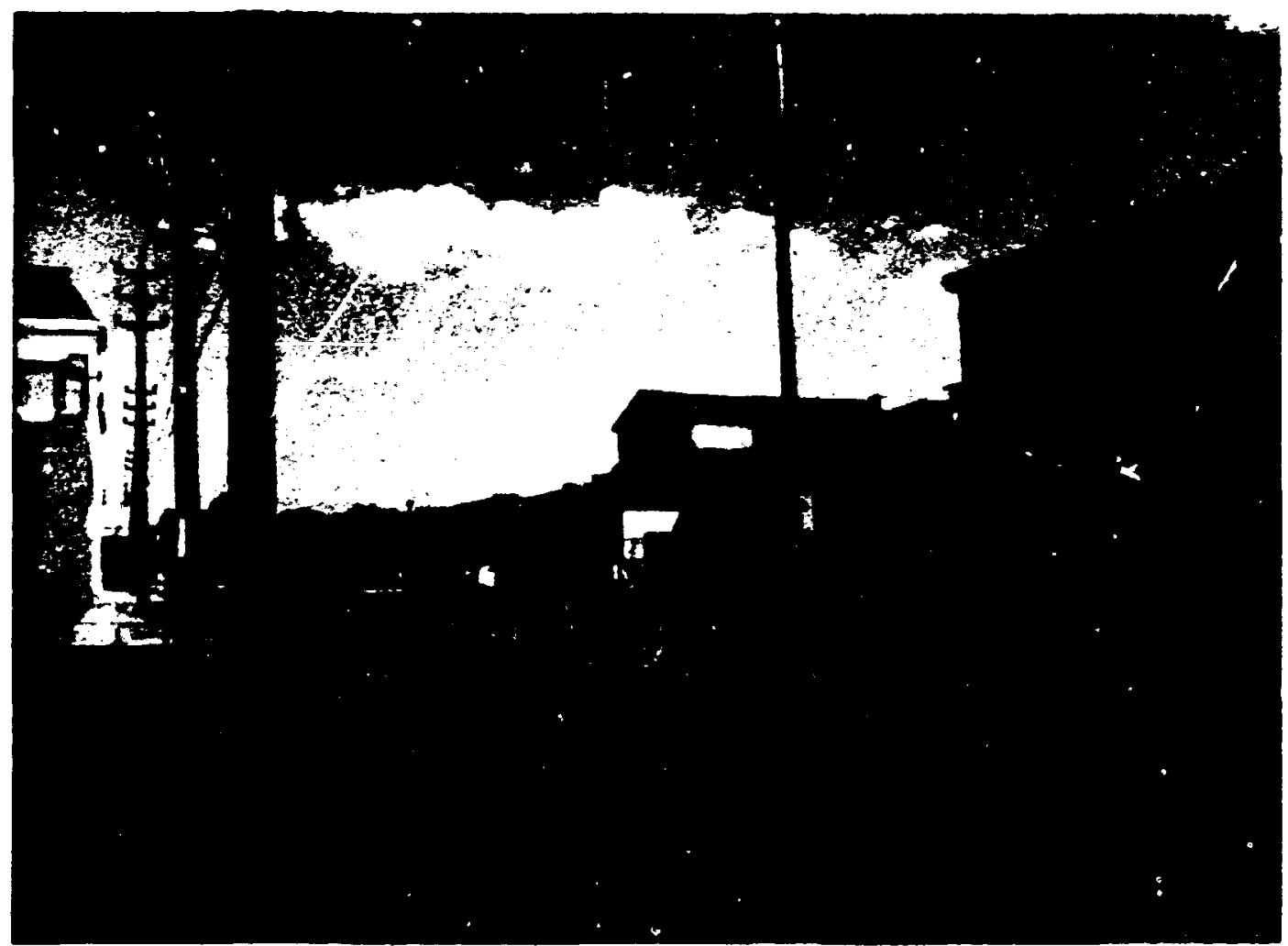

Fig. 2. View of the back of the building at Diebold Safe Company, 1550 Grand Boulevard, Hamilton, Ohio (HO001), from Erie Highway looking north. 


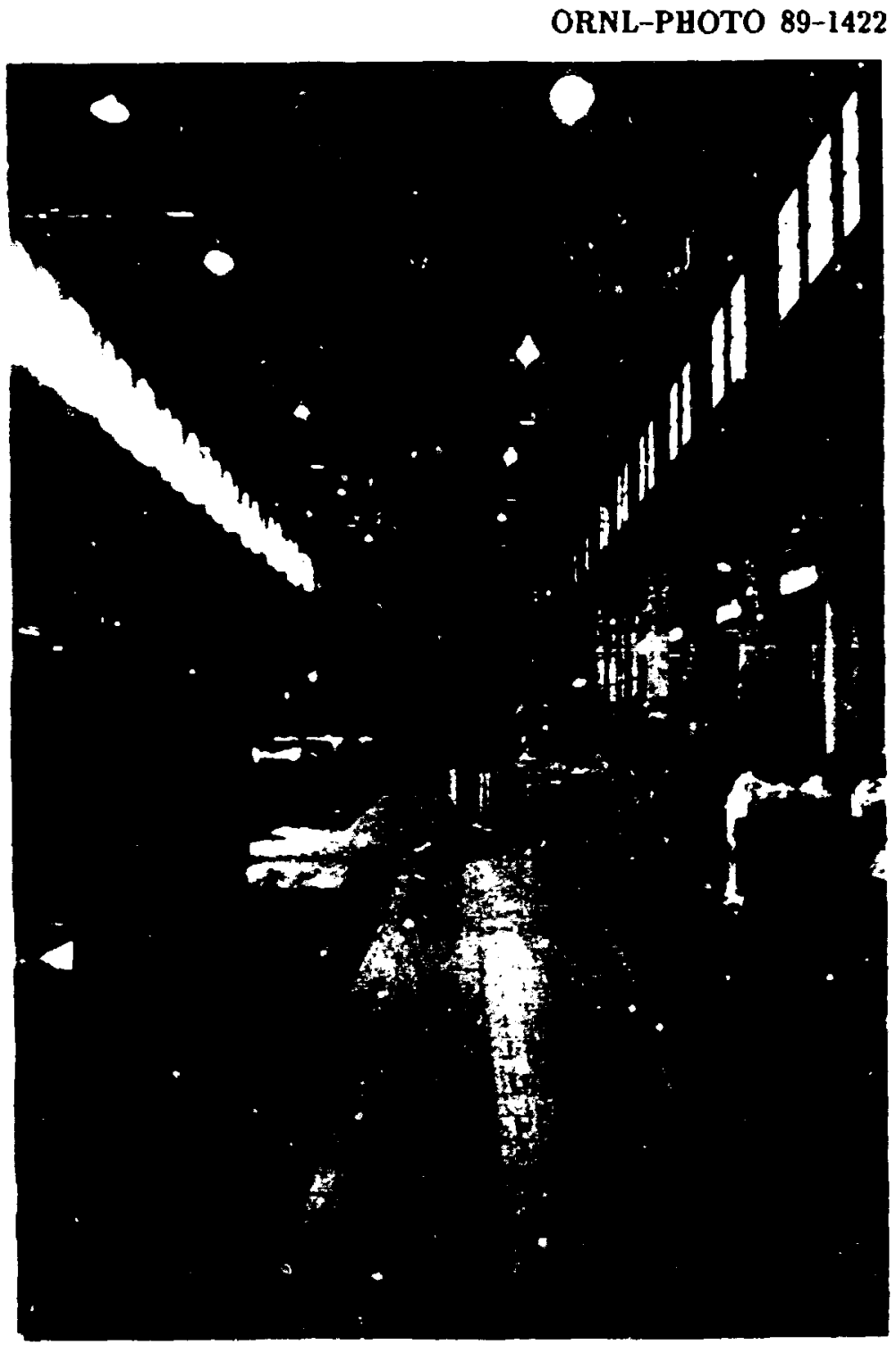

Fig. 3. Interior view of the building at Diebold Safe Company, 1550 Grand Boulevard, Hamilton, Ohio (HOO01), showing one high bay area with windows between columns $\mathrm{T}$ and $\mathrm{V}$. 


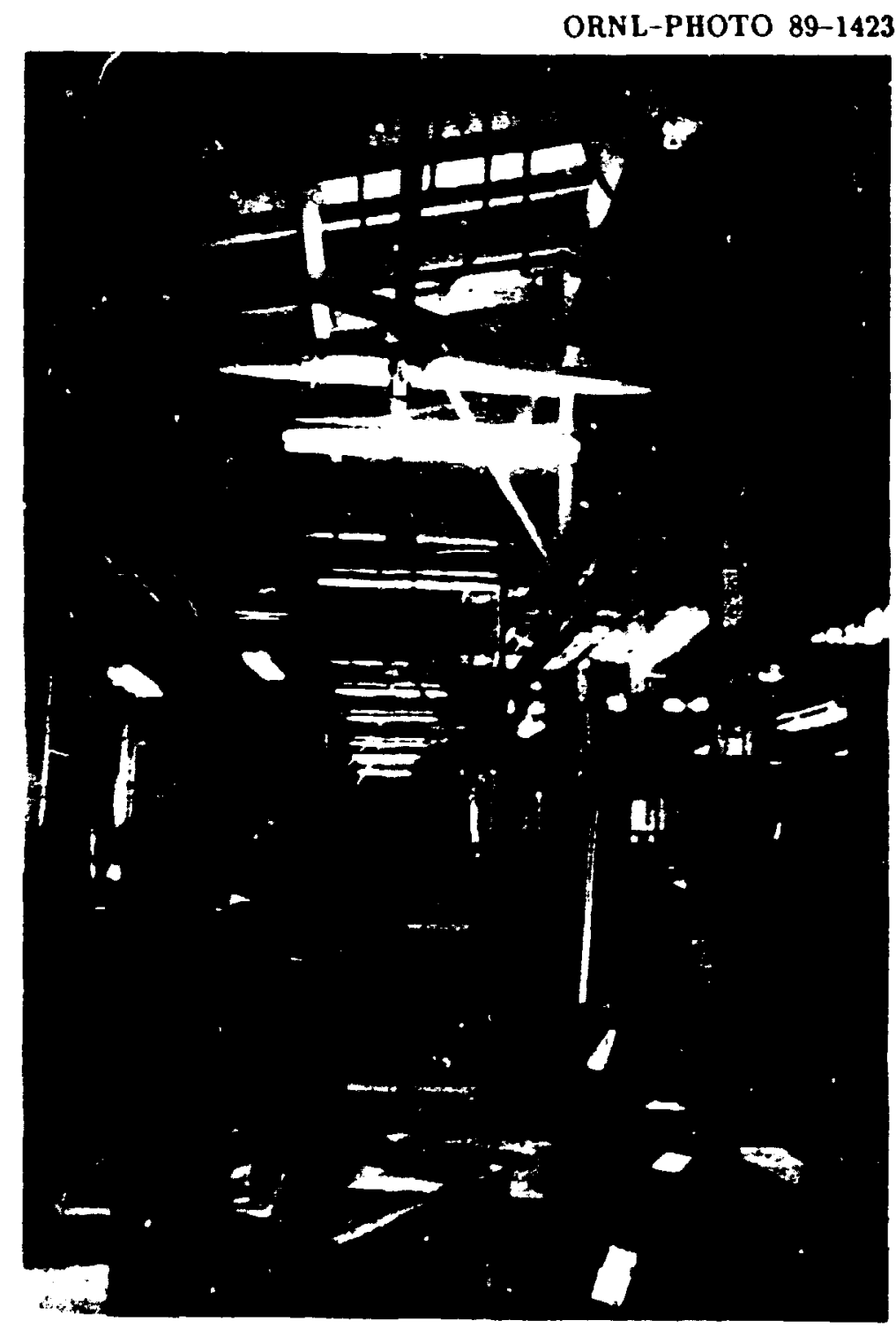

Fig. 4. Interior view of the building at Diebold Safe Company, 1550 Grand Bonlevard, Hamilton, Ohio (HOO01), showing the cross brares. 


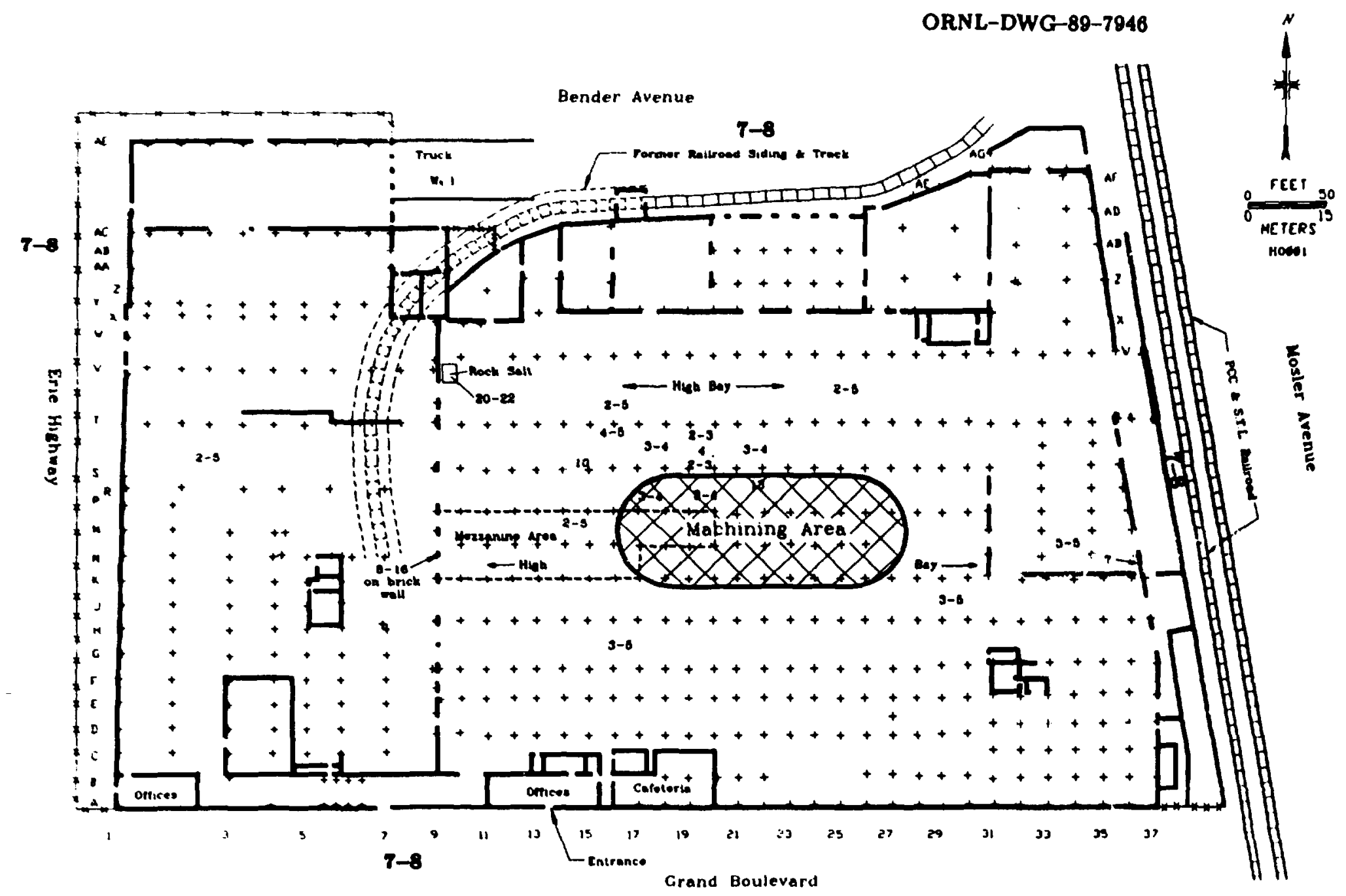

Fig. 5. Ganma radiation levels $(\mu \mathrm{R} / \mathrm{h})$ measured both indoors snd outdoors at Diebold Safe Company, 1550 Grand Boulevard, Hamilton, Ohio (HO001). 


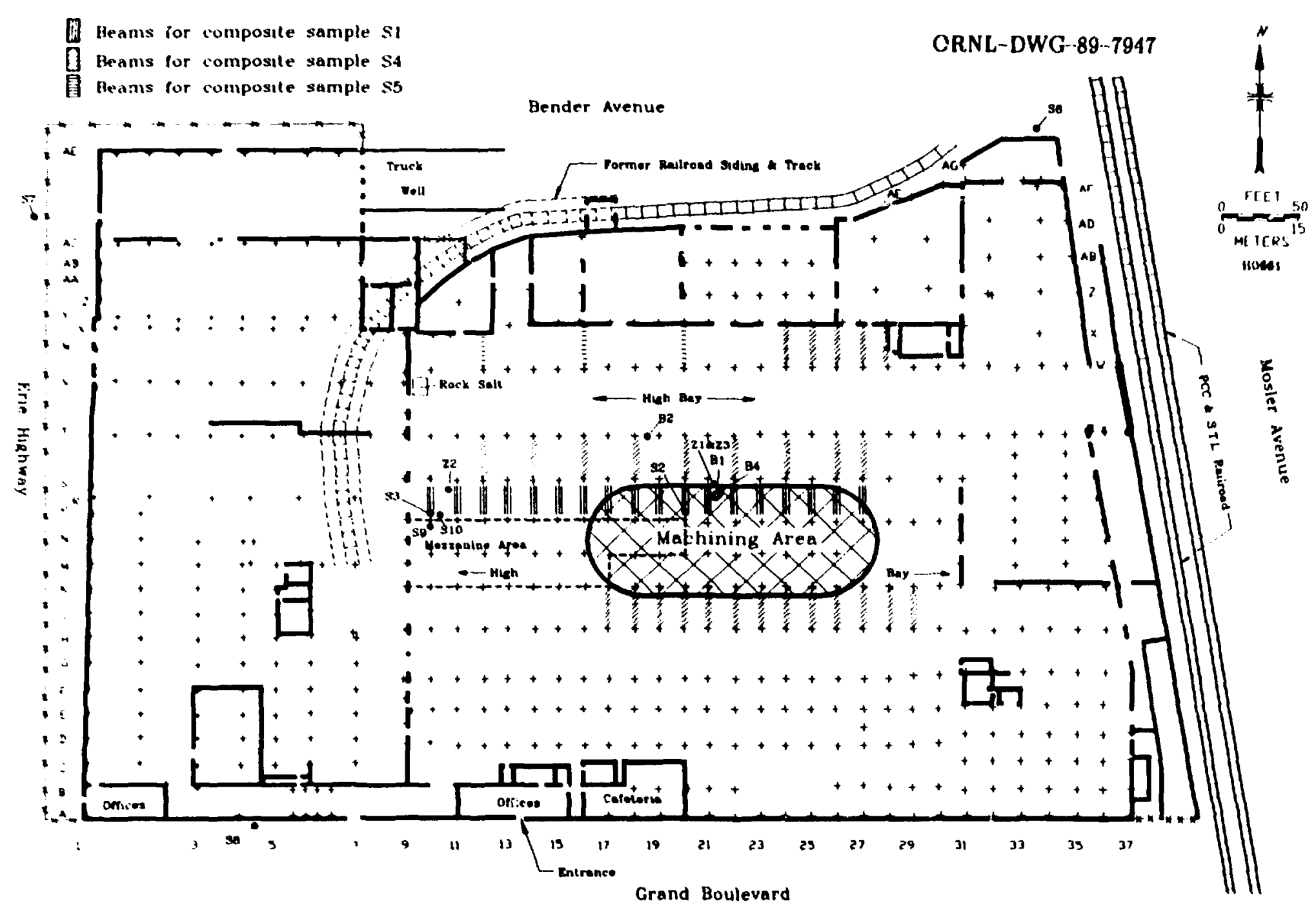

Fig. 6. Diagram showing locations of soil, dust, debris, and air samples taken at Diebold Safe Company, 1550 Grand Boulevard, Hamilton, Ohio (HO001). 
Table 1. Applicable guidelines for protection against radiation ${ }^{a}$

\begin{tabular}{|c|c|c|}
\hline Mode of expr.sure & Exposure conditions & Guideline value \\
\hline Gamma radiation & $\begin{array}{l}\text { Indoor gamma radiation levels } \\
\text { (above Background) }\end{array}$ & $20 \mu R / h$ \\
\hline \multirow[t]{2}{*}{$\begin{array}{l}\text { Surface contam } \\
\text { ination }\end{array}$} & $\begin{array}{l}{ }^{238} \mathrm{U}, \mathrm{U} \text {-natural } \\
\text { Fixed on surfaces } \\
\text { Removable }\end{array}$ & $\begin{array}{l}5000 \mathrm{dpın} / 100 \mathrm{~cm}^{2} \\
1000 \mathrm{dpm} / 100 \mathrm{~cm}^{2}\end{array}$ \\
\hline & $\begin{array}{l}\text { Beta-gamma emitters }{ }^{c} \\
\text { Fixed on surfaces } \\
\text { Removable }\end{array}$ & $\begin{array}{l}5000 \mathrm{dpm} / 100 \mathrm{~cm}^{2} \\
1000 \mathrm{dpm} / 100 \mathrm{~cm}^{2}\end{array}$ \\
\hline \multirow[t]{2}{*}{$\begin{array}{l}\text { Beta-gamma dose } \\
\text { rates }\end{array}$} & $\begin{array}{l}\text { Surface dose rate averaged } \\
\text { over not more than } 1 \mathrm{~m}^{2}\end{array}$ & $0.20 \mathrm{mrad} / \mathrm{h}$ \\
\hline & $\begin{array}{l}\text { Marimurn dose rate in any } \\
100 \mathrm{~cm}^{2} \text { arca }\end{array}$ & $1.0 \mathrm{mrad} / \mathrm{h}$ \\
\hline $\begin{array}{l}\text { Radionuclide concentra- } \\
\text { tions in soil and in vari- } \\
\text { ous indoor samples }\end{array}$ & $\begin{array}{l}\text { Maximum permissible concentra- } \\
\text { tion of the following radionu- } \\
\text { clides in soil above background } \\
\text { levels averaged over } 100 \mathrm{~m}^{2} \\
\text { area } \\
{ }^{232} \mathrm{Th} \\
{ }^{230} \mathrm{Th} \\
{ }^{228} \mathrm{Ra} \\
{ }^{226} \mathrm{Ra} \\
{ }^{238} \mathrm{U}\end{array}$ & $\begin{array}{l}5 \mathrm{pCi} / \mathrm{g} \text { averaged over the first } 15 \\
\mathrm{~cm} \text { of soil below the surface } 15 \\
\mathrm{pCi} / \mathrm{g} \text { when averaged over } 15- \\
\mathrm{cm} \text { thick soil layers more than } \\
15 \mathrm{~cm} \text { below the surface }\end{array}$ \\
\hline $\begin{array}{l}\text { Guidelines for nonhomo- } \\
\text { geneous contamination } \\
\text { (used in addition to the } \\
100 \mathrm{~m}^{2} \text { guideline) }\end{array}$ & $\begin{array}{l}\text { Applicable to locations mecting } \\
\text { the above criterion but } \leq 25 \mathrm{~m}^{2} \\
\text { with significantly elevated con- } \\
\text { centrations of radionuclides }\end{array}$ & $\begin{array}{l}\text { Concentration limits for applica- } \\
\text { tion to "hot spots" varying in } \\
\text { size as follows: } \\
\begin{array}{cc}\left(\mathrm{m}^{2}\right) & (\mathrm{pCi} / \mathrm{g})^{g} \\
<1 & 50 \\
1-<3 & 30 \\
3-<10 & 15 \\
10-25 & 10\end{array}\end{array}$ \\
\hline
\end{tabular}

\footnotetext{
a Reference 4 .

${ }^{b}$ DOF, surface contamination guidelines are consistent with the Nuclear Rrgulatory Commission guidelines found in Reference 5.

${ }^{C}$ Beta gamma emilters (radionuclides with decay moxles other than alpha emission or apontaneous

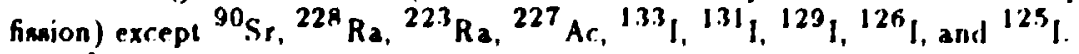

dIndoor samplex taken for analyses of radionuclide concentrations consisted of duat samplex, fioor debris, polishing compound, and sanding belts.

'DOF, guidelines for uranium are derived on a site sperific basis. While none have bern derived ferr this site, guidelines for 238 ; typucally range between 35 and $150 \mathrm{p}, \mathrm{i} / \mathrm{g}$.

f "fivery reawnable effort whall be made to identify and remove any source which has a concentration exceeding 30 times the guideline value, irsespertive of arra."

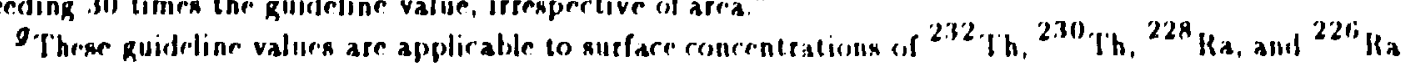
only; for other radienuelides and subsurfare values, were Refesem.....
} 
Table 2. Background radiation levels for the Ohio area outdoors

Type of radiation measurement or sample
Radiation level or radionuclide concentration

Concentration of radionuclides in soil $(\mathrm{pCi} / \mathrm{g})$
${ }^{226} \mathrm{Ra}$
$1.5^{a}$
${ }^{232} \mathrm{Th}$
$1.0^{a}$
${ }^{238} \mathrm{U}$
$1.4^{a}$

${ }^{a}$ Reference 6. 
Table 3. Concentrations of radionuclides in outdoor soil samples from Diebold Safe Company, 1550 Grand Boulevard, Hamilton, Ohio (HO001)

\begin{tabular}{|c|c|c|c|c|}
\hline \multirow{2}{*}{ Sample ${ }^{a}$} & \multirow[b]{2}{*}{$\begin{array}{c}\text { Depth } \\
(\mathrm{cm})\end{array}$} & \multicolumn{3}{|c|}{ Radionuclide concentration ( $\mathrm{pCi} / \mathrm{g}$ ) } \\
\hline & & ${ }^{226} \mathrm{Ra}^{6}$ & ${ }^{232} \mathrm{Th}^{b}$ & ${ }^{238} \mathrm{U}^{\mathbf{b}}$ \\
\hline \multicolumn{5}{|c|}{ Systematic samples } \\
\hline $\begin{array}{l}\text { S6 } \\
\text { S7 } \\
\text { S8 }\end{array}$ & $\begin{array}{l}0-15 \\
0-15 \\
0-15\end{array}$ & $\begin{array}{l}1.06 \pm 0.02 \\
0.97 \pm 0.02 \\
1.22 \pm 0.02\end{array}$ & $\begin{array}{l}0.67 \pm 0.03 \\
0.59 \pm 0.03 \\
0.78 \pm 0.04\end{array}$ & $\begin{array}{l}1.38 \pm 0.55 \\
1.51 \pm 0.42 \\
1.55 \pm 0.58\end{array}$ \\
\hline
\end{tabular}

'Locations of soil samples are shown on Fig. 6.

Indicated counting error is at the $95 \%$ confidence level $( \pm 2 \sigma)$.

'Systematic samples are taken at locations irrespective of gamma exposure rates. 
Table 4. Concentrations of radionuclides in indoor dust, debris, and polishing compound samples from Diebold Safe Company, 1550 Grand Boulevard, Hamilton, Ohio (HO001)

\begin{tabular}{|c|c|c|c|c|c|}
\hline \multirow{2}{*}{ Sample ${ }^{a}$} & \multirow{2}{*}{ Type } & \multicolumn{4}{|c|}{ Radionuclide concentration $(\mathrm{pCi} / \mathrm{g})$} \\
\hline & & ${ }^{226} \mathrm{Ra}^{\mathrm{b}}$ & ${ }^{232} \mathrm{Th}^{6}$ & ${ }^{238} \mathrm{U}^{6}$ & \\
\hline \multicolumn{6}{|c|}{ Systematic samples } \\
\hline $\begin{array}{l}\mathrm{S}^{d} \\
\mathrm{~S} 2 \\
\mathrm{~S} 3 \\
\mathrm{~S} 4^{d} \\
\mathrm{~S}^{d} \\
\mathrm{~S} 9^{e} \\
\mathrm{~S} 10^{e}\end{array}$ & $\begin{array}{l}\text { Dust } \\
\text { Dust } \\
\text { Dust } \\
\text { Dust } \\
\text { Dust } \\
\text { Dust } \\
\text { Dust }\end{array}$ & $\begin{array}{l}0.58 \pm 0.01 \\
0.40 \pm 0.01 \\
1.19 \pm 0.08 \\
0.66 \pm 0.01 \\
0.74 \pm 0.03 \\
0.84 \pm 0.04 \\
0.77 \pm 0.05\end{array}$ & $\begin{array}{l}0.51 \pm 0.02 \\
0.22 \pm 0.02 \\
0.89 \pm 0.13 \\
0.60 \pm 0.02 \\
0.75 \pm 0.05 \\
0.76 \pm 0.7 \\
0.76 \pm 0.07\end{array}$ & $\begin{array}{r}2.27 \pm \\
1.72 \pm \\
14.67 \pm \\
3.20 \pm \\
3.75 \pm \\
3.1 \pm \\
4.5 \pm\end{array}$ & $\begin{array}{l}0.34 \\
0.29 \\
2.18 \\
0.50 \\
0.51 \\
2.9 \\
2\end{array}$ \\
\hline \multicolumn{6}{|c|}{ Biased samples $f$} \\
\hline $\begin{array}{l}\text { B1 } \\
\text { B2 } \\
\text { B3 }^{\text {h }} \\
\text { B4 }^{\text {i }}\end{array}$ & $\begin{array}{l}\text { Debris } \\
\text { Debris } \\
\text { Bison } \\
\text { Debris }\end{array}$ & $\begin{array}{c}g \\
g \\
g \\
0.69 \pm 0.06\end{array}$ & $\begin{array}{l}0.14 \pm 0.014 \\
0.09 \pm 0.011 \\
2.05 \pm 0.14 \\
0.48 \pm 0.08\end{array}$ & $\begin{array}{c}2000 \pm 1 \\
26 \pm \\
0.68 \pm \\
38.2 \pm\end{array}$ & $\begin{array}{l}60 \\
1.89 \\
0.08 \\
2.5\end{array}$ \\
\hline
\end{tabular}

- Locations of indoor samples are shown on Fig. 6.

${ }^{6}$ Indicated counting error is at the $95 \%$ confidence level $( \pm 2 \sigma)$.

'Systematic samples are taken at locations irrespective of gamma exposure rates.

${ }^{d}$ Samples S1, S4, and S5 were three composites of dust collected from the tops of presected beams.

- Dust samples S3 and S10 were taken near S3 at a later date and contained radionuclide concentrations below those of S3. See text for details.

fBiased samples are taken from areas shown to have elevated gamma exposure rates.

${ }^{9}$ Sample was not analyzed for ${ }^{226} \mathrm{Ra}$.

${ }^{\text {hSample }}$ B3 was the Bison Corporation Satin Finish Buffing and Polishing Compound.

'Debris sample B4 was taken at a later date from the same loxation as sample B1. See text for retails. 
Table 5. Concentrations of radionuclides in air samples from Diebold Safe Company, 1550 Grand Boulevard, Hamilton, Ohio (HO001)

\begin{tabular}{|c|c|c|c|c|c|c|}
\hline Sample ${ }^{a}$ & Date & Location & Time & $\begin{array}{c}\text { Elapsed Time } \\
\text { (minutes) }\end{array}$ & $\begin{array}{l}\text { Volume } \\
\text { (liters) }\end{array}$ & $\begin{array}{c}\text { Activity } \\
\text { (dpm) }\end{array}$ \\
\hline \multicolumn{7}{|c|}{ Air sampless } \\
\hline $\begin{array}{l}\text { Z1 } \\
\mathrm{Z2} \\
\mathrm{Z3}\end{array}$ & $\begin{array}{l}4 / 24 / 89 \\
4 / 24 / 89 \\
4 / 24 / 89\end{array}$ & $\begin{array}{l}\text { S-21 } \\
\text { S-11 } \\
\text { S-21 }\end{array}$ & $\begin{array}{l}16: 50 \\
15: 05 \\
18: 53\end{array}$ & $\begin{array}{c}96 \\
127 \\
55\end{array}$ & $\begin{array}{l}2175 \\
2877 \\
1246\end{array}$ & $\begin{array}{l}<\mathrm{MDA}^{d}{ }^{d} \\
<\mathrm{MDA}^{\mathrm{M}} \\
<\mathrm{MDA}\end{array}$ \\
\hline
\end{tabular}

a Locations of air samples are shown on Fig. 6.

${ }^{b} \mathrm{Gross}$ radionuclide activity is reported in disintegrations per minute (dpm).

${ }^{c}$ Air samples are taken at $1.5 \mathrm{~m}$ above floor level.

${ }^{d}$ Minimum detetable amount (MDA) for ${ }^{238} \mathrm{U}$ is $<5 \%$ of the U.S. DOE Order 5480.11, December 21, 1988, via inhaled air, Y-Class. 
This report has been reproduced directly from tho beet aveibuble copy.

Aveiabie to DOE and DOE contractors from the Oitice of Scientific and Techical hiformation, P.O. Box 62. Oak Pidge. TN 37831; prices avainble from (615) 576-401, FTS 626-8401.

Avalable to the putic from the Nationed Techniced Information Service. U.S. Depertment of Commerce, 5285 Port Royed Rd., Sprindield, VA 22161. NTS price codeo-Printed Copy: AO3 Nicrofich $\mathrm{NO1}^{\circ}$

This report was prepared as an account of work sponeored by an eqency of the United Statee Government. Neither the United Statee Government nor any egency thereof. nor any of their employeces, makes any werrenty, exprese or implied, or ascumes any legal liabiity or reeponability for the eccurecy. com pletences, or uectuhness of any information, apparatus, product, or procees dicloced, or reprecents thet its use would not infringe privately owned rights. Peterence herein to any epecific commerciel product, procees, or senvice by trede name, tredemark, manutacturer, or othenwios. does not maceasarly conetitute or imply its endoreement, recommendation, of favoring by the United States Government or any ecency therest. The viowe and opinione of authora expreased herein do not necessarity state or reflect those of the United States Government or any agency thereof. 